\title{
The Modified Control Method for the Single-Stage Three-Phase Grid- Connected Photovoltaic System
}

- Phan Quoc Dzung

- Nguyen Truong Dan Vu

- Le Dinh Khoa

- Nguyen Bao Anh

- Le Chi Hiep

University of Technology, VNU-HCM

(Manuscript Received on August 28 ${ }^{\text {th }}$, 2013, Manuscript Revised November 03 ${ }^{\text {rd }}$, 2013)

\begin{abstract}
:
Single-stage topology and the maximum power point tracking (MPPT) algorithm have advantages such as simple configuration and high efficiency in grid-connected photovoltaic $(P V)$ systems. In conventional systems, current and voltage sensors of PV system are normally used for MPPT. This paper presents a modified control algorithm for the single-stage three-phase grid-connected PV system without $P V$ current sensor with a variable step MPP-tracker. This algorithm is not derived from complex state equations
\end{abstract}

and is not dependent on any circuit parameters. It simply calculates the output power of the inverter to replace the input power of the PV systems in the MPPT algorithm. The modified algorithm is simulated by using Matlab/Simulink software and implemented in the experimental prototype. With the single-stage configuration and PV current sensorless method, the prototype is suitable for lowcost high efficient implementation in the practice.

Keywords: Single Stage Configuration, MPPT, Photovoltaic System.

\section{INTRODUCTION}

Nowadays, PV energy system is one of important source for sustainable development in most of countries all over the world. It features pure source and easy-to-install system. Moreover, it does not require complex and usual maintenance. Often, there are two categories for photovoltaic (PV) systems: 1) standalone system and 2) direct grid-connected system. Standalone

systems are in low-power application and use many battery banks for power reservation. In direct grid-connected application, the PV system power is converted and directly injected into electricity grid.

The PV power and voltage have a non-linear relationship. Therefore, it is indispensable to operate a PV system in maximum power point. 
The maximum power point (MPP) is dependent on environmental elements, such as irradiation, temperature. The maximum power point tracking (MPPT) algorithms are developed for those PV systems always produce the maximum power regardless of the environment. During years, many MPPT methods have been developed and implemented such as Hill Climbing/P\&O, Incremental Conductance (IncCond), Fractional Open-Circuit Voltage or Short-Circuit Current methods, based on Fuzzy logic or Neural Network methods [1-7].

The maximum power point tracker (MPPTer) usually requires two sensors in the input side for PV system voltage and current. However, the PV system voltage, current and grid currents have relation based on mathematical equations. Thus, some strategies are developed to estimate the information of PV system voltage or PV system current without sensors. These algorithms are often affected by circuit parameters or based on complex theory of observer [8], [9]. These problems make the algorithms difficult to implement in practice.

The single-stage grid-connected PV systems have been presented in many publications [10-
14]. In these systems, both current and voltage sensors of PV array are usually used to realize MPPT. In the other work [15], unlike other MPPT methods, only PV array's output voltage is required to be sensed to implement MPPT. However, the algorithm for this scheme is quite complex and suitable only for a single phase grid-connected inverter.

With a goal to minimize the cost and control complexity, this paper presents a low-cost singlestage three-phase grid- connected PV system without the PV array's output current sensor. The modified algorithm observes the output power of inverter instead of the input power of PV system.

\section{CONVENTIONAL AND PROPOSED SINGLE-STAGE THREE-PHASE GRID- CONNECTED PV SYSTEM WITH MPPT ALGORITHM}

Single-stage configuration is used to remove the DC/DC converter. This configuration is useful to increase the efficiency and decrease overall cost (Fig.1). Fig.2 and the equation (1) show the relationship between DC-link voltage, inverter and grid voltages.

$$
\frac{2}{\pi} \cdot 0.9 \cdot U_{D C-\operatorname{link}}=v_{i}=\sqrt{(\omega L i)^{2}+v_{g}^{2}}
$$

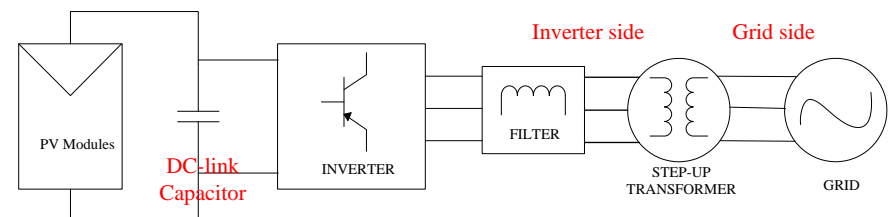

Figure 1. Single-stage three- phase grid- connected PV configuration with step-up transformer

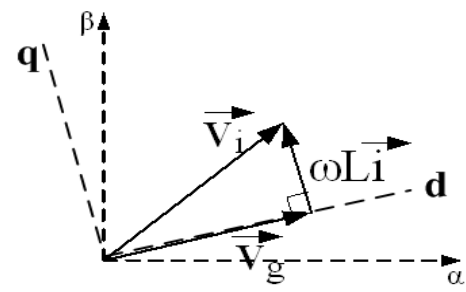

Figure 2.Relationship between DC-link, inverter and grid voltages 


\section{Conventional control algorithm for single stage PV system}

MPPT algorithm for single-stage configuration is based on $\mathrm{U}_{\mathrm{dc}}$-controling ability of the inverter. The inverter changes the altitude of $I_{d}$ (d-axis value of grid-current-space-vector in the gridvoltage-coordinate) to change $\mathrm{U}_{\mathrm{dc}}$ into $\mathrm{U}_{\mathrm{dc}-\text {-reference. }}$ MPPTer detects the maximum power point $\left(\mathrm{V}_{\text {ref }}\right.$ $\left.=\mathrm{V}_{\mathrm{MPP}}\right)$. Afterthat, the inverter will keep the $\mathrm{U}_{\mathrm{dc}}$ approximately equal to this value as showing in Figure $3 a$.

Block MPPT: using any MPPT algorithms such as $\mathrm{P} \& \mathrm{O}$, Incremental Conductance.. Receiving PV system voltage and current, this block determines the optimal voltage for operating in next step. The output voltage $\mathrm{V}_{\text {ref }}$ is kept closer and closer the maximum power voltage.

Block Control: controlling three currents injected into grid. Some methods can be used to control the currents [16], [17]: PI control, hysteresis control (Fig.3b), deadbeat control... In this paper, the hysteresis algorithm is used because of simplicity and flexibility. Often, $\mathrm{I}_{\mathrm{q} \_ \text {ref }}$ is kept zero so that the grid current and the grid phase voltage are in the same phase, unity power factor. Beside that, $\mathrm{I}_{\mathrm{q} \_ \text {ref }}$ can be different from zero to compensate the reactive power as desired.

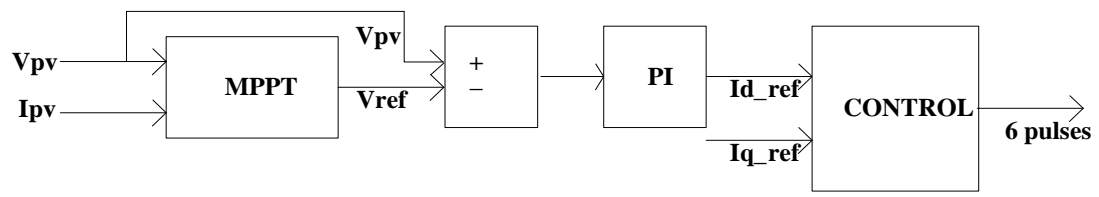

a) Control block-schema for single-stage PV system

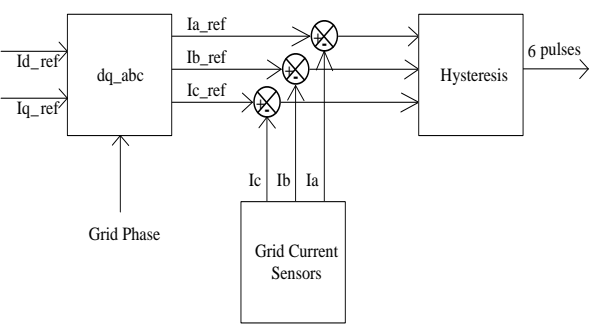

b) Hysteresis Current Control

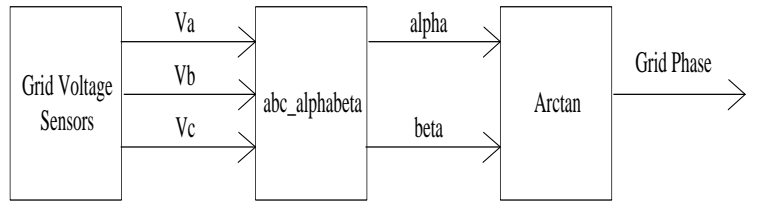

c) Grid Voltage Phase Detecting

Figure 3.Control block-schema for single-stage PV system

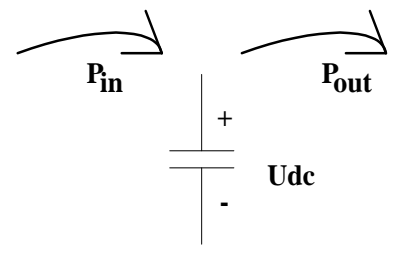

Pin $=$ Pout $:$ Udc constant

Pin > Pout: Udc increased

Pin < Pout : Udc decreased

Figure 4. Relationship between DC-link value and Power Flow 


\section{Principle of DC-link Voltage Balance}

Active power $\mathrm{P}$ and reactive one $\mathrm{Q}$ are controlled by tuning the values of $I_{d}$ and $I_{q}$ of grid currents. Where $\left(\mathrm{I}_{d}, \mathrm{I}_{\mathrm{q}}\right)$ is two components of grid current space vector in the rotation grid voltage coordinate, $\mathrm{d}$-axis is identical with the grid voltage space vector (Fig.3c). The simultaneous value of $(\mathrm{P}, \mathrm{Q})$ injected into grid must ensure the stability of DC-link voltage. As mentioned above, $\mathrm{Q}$ is often set to zero, only $\mathrm{P}$ is changed to stabilize DC-link voltage (Fig.4).

In addition, the active power $\mathrm{P}$ can be calculated in terms of the Id component:

$$
P=3 \cdot V_{g d} \cdot I_{d}
$$

where Vgd is grid voltage and Id is grid current. Thus, control loop can change Id value to keep the DC-link voltage fixed.

$\left\{\begin{array}{l}U_{D C}>U_{D C} \text { ref }: \text { increase } I_{d_{-}} \text {ref } \\ U_{D C}<U_{D C} \text { ref }: \text { decrease } I_{d_{-} r e f}\end{array}\right.$

The grid currents presented in this paper have the assigned direction from inverter to grid.

The proposed control algorithm for single stage three-phase PV system

The proposed algorithm uses only voltage sensor of PV array output and the MPPTer has to be detect the MPP (Fig.5).

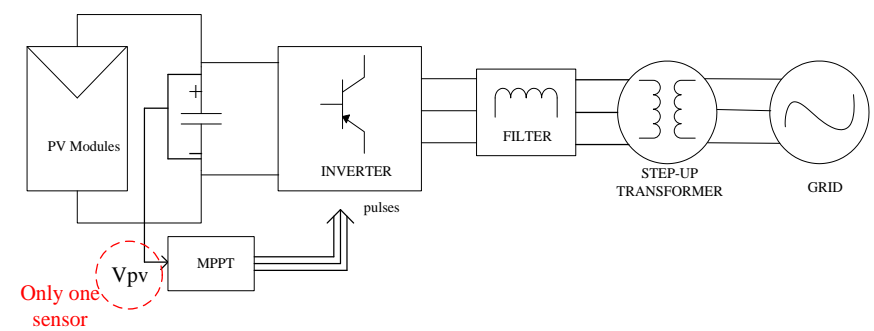

Figure 5. Low-cost single stage three-phase grid-connected PV system

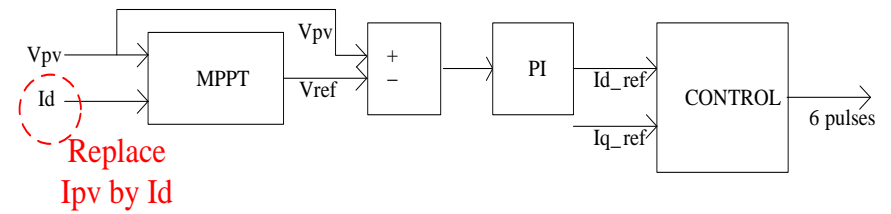

Figure 6. The block-schema of proposed control algorithm

In the block schema of proposed control algorithm (Fig. 6), the input of MPPT block includes $V_{P V}$ and $I_{d}$. Due to principle of DC-link voltage control, the input power and the output power will be equal when Udc-link value balances out. Therefore, instead of $\mathrm{P}_{\mathrm{in}}$ observation, the MPPT block can observe $\mathrm{P}_{\text {out }}$ to track the MPP. In this case, PV current value is unnecessary for MPPT because the MPPT block do not need to know the PV power, so the current sensor for PV array can be removed. The new algorithm will control the PV voltage operation point to attain the maximum value of $I_{d}$.

At the beginning, the MPPTer will adjust the DC-link voltage $\left(\mathrm{V}_{\mathrm{PV}}\right)$ to be equal to the initial voltage reference $\left(\mathrm{V}_{\text {ref }}\right)$. It may be done by using the fractional open circuit voltage MPPT method, as following:

$$
V_{R E F_{-} I N I T}=(0.6 \div 0.8) \cdot V_{O C}
$$

where $\mathrm{V}_{\mathrm{OC}}$ - the open circuit voltage of $\mathrm{PV}$ array

\section{Trang 22}


When the $V_{P V}$ is steady, the $I_{d}$ value will be observed. If the $I_{d}$ value in this step is bigger than the previous step value, $V_{\text {ref }}$ will be changed as same way as the previous step. Otherwise, $V_{\text {ref }}$ will be changed as inverse way as the previous step (Fig.7). Thus, the stable $V_{\text {ref }}$ is in the operation point having maximum $\mathrm{I}_{d}$ value.

The proposed algorithm is based on the method with variable step change of $\mathrm{V}_{\text {ref. }}$ Unlike other MPPT methods, the input power is substituted by $I_{d}$ value which is easy to calculate (Fig.7). In addition, the $I_{d_{-} \text {ref }}$ is observed instead of $I_{d}$ because the $I_{d \_r e f}$ value has a little noise than $I_{d}$ value and relatively identical to $I_{d}$ in steady state.
In case of using fixed step, if the step size is large, the PV operation point will reach to MPP rapidly but oscillate around this point. In opposite way, if the step size is small, the operation point will be steady at the MPP but it takes a long time to reach to this point. To overcome this drawback, the proposed MPPT method uses variable voltage step size as below equation (5), the step size depends on the difference of $I_{d(k)}$ and $\mathrm{I}_{\mathrm{d}(\mathrm{k}-1)}$. In this equation, the value of coefficient $\mathrm{K}$ is determined by using such as the optimizationbased algorithm.

$$
d V=K\left|I_{d}(k)-I_{d}(k-1)\right|
$$

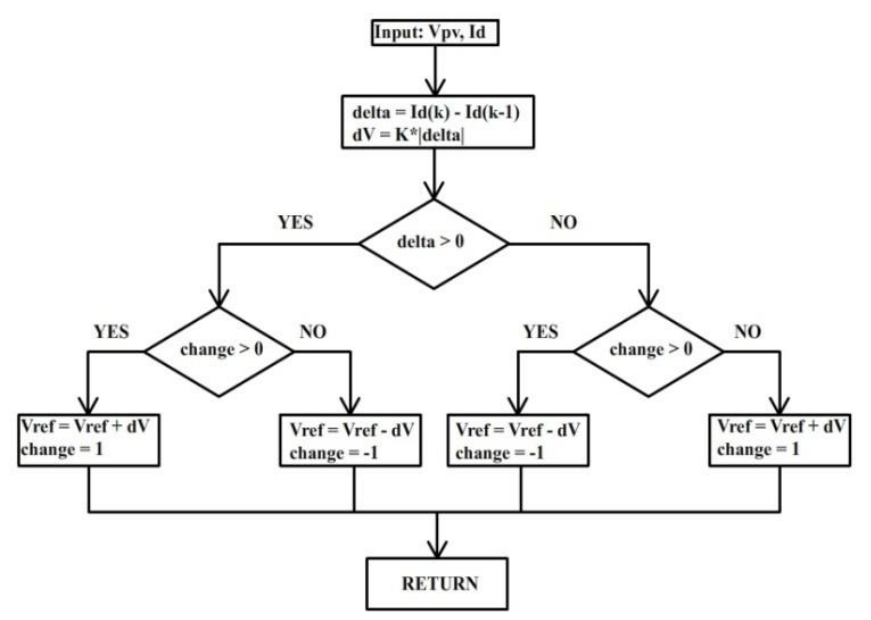

Figure 7. The flowchart of proposed variable step change of MPPT algorithm

The variable step size can combine two advantages of small step size and large step size; they are fast response time and stable operation point. At the starting, the operation point is far from MPP, the difference $\left(I_{d(k)}-I_{d(k-1)}\right)$ is big, so the step size $\mathrm{dV}$ is also big to get MPP rapidly. After a short time, the operation point is moved to MPP, the difference $\left(\mathrm{I}_{\mathrm{d}(\mathrm{k})}-\mathrm{I}_{\mathrm{d}(\mathrm{k}-1)}\right)$ is small gradually and is equal to zero when it reaches to MPP, so dV is smaller than the previous one and remains zero at MPP to get the stable operation point.

\section{Model of estimating power loss and efficiency of VSI}

Estimating efficiency of solar inverters is usually based on calculating power loss of switching device [20-23]. Calculating the power loss of semiconduting switches is expressed as the following.

When a switch is operating, there are four types of power loss: conducting loss, off-state loss, switching loss, driving loss. Comparing with conducting loss and switching loss, off-state loss and driving loss are so small that they can be 
neglected. The switching loss depends on the switching energy ( $\mathrm{E}_{\mathrm{ON}}$ and $\left.\mathrm{E}_{\mathrm{OFF}}\right)$ and switching frequency, the conducting loss depends on voltage $\left(\mathrm{V}_{\mathrm{CEO}}\right)$, resistance $\left(\mathrm{R}_{\mathrm{CEO}}\right)$ and value of current which is through the semiconducting device. The above parameters is provided by the producers, they can be selected appropriately according to operating condition and operating mode.

Energy converting efficiency of VSI is based on estimating the total power loss of semiconducting switches and it is calculated by the following formula:

$$
\eta=\frac{P_{d c}-P_{L_{-} \text {total }}}{P_{d c}} \cdot 100 \%
$$

With $\eta$ is efficiency, $P_{\text {in }}$ is input power of VSI $\mathrm{P}_{\text {Ltotal }}$ is power loss of semiconducting switches.

The input power of VSI is determined by the formula:

$$
P_{d c}=V_{i n} \cdot I_{i n}
$$

\section{Estimating power loss of IGBT}

Power loss of IGBT consists of conducting loss and switching loss, it is calculated by the following formula:

$P_{I G B T}=\left(V_{C E O} \cdot I_{C(A V)}+R_{C E O} \cdot I_{C(R M S)}^{2}\right)+\left(E_{O N}+E_{O F F}\right) \cdot \frac{V_{C E_{-} b l}}{V_{C E_{-} r e f}} \cdot \frac{i_{C}}{I_{C_{-} \text {ref }}} \cdot f_{S w}$

With $\mathrm{V}_{\mathrm{CEO}}$ : on-state zero-current collectoremitter voltage

$\mathrm{R}_{\mathrm{CEO}}$ : collector-emitter on-state resistance

$\mathrm{E}_{\mathrm{ON}} \quad$ : turn -on energy

EOFF : turn -off energy

$\mathrm{I}_{\mathrm{C}(\mathrm{AV})}$ : average value of collector current

$\mathrm{I}_{\mathrm{C}(\mathrm{RMS})}$ : RMS value of collector current

$\mathrm{V}_{\mathrm{CE} \_\mathrm{bl}}$ : blocking collector-emitter voltage

$\mathrm{V}_{\mathrm{CE} \_ \text {ref: }}$ blocking collector-emitter voltage from datasheet
I C ref $_{\text {_ }}$ : collector current from datasheet

$\mathrm{i}_{\mathrm{C}} \quad$ : collector current

$\mathrm{f}_{\mathrm{sw}} \quad$ : switching frequency

\section{Estimating power loss of Diode}

Power loss of a didoe is similar to above, it is calculated by the following formula:

$P_{\text {Diode }}=\left(V_{D} \cdot I_{D(A V)}+R_{D} \cdot I_{D(R M S)}^{2}\right)+E_{r r} \cdot \frac{V_{r}}{V_{r_{-} r e f}} \cdot \frac{i_{d}}{I_{d_{-} r e f}} \cdot f_{s w}$

With $\mathrm{V}_{\mathrm{D}}$ : on-state voltage

$\mathrm{R}_{\mathrm{D}} \quad$ : on-state resistance;

$\mathrm{E}_{\mathrm{rr}} \quad$ : reverse recovery energy

$\mathrm{I}_{\mathrm{D}(\mathrm{AV})}$ : average value of forward current

$\mathrm{I}_{\mathrm{D}(\mathrm{RMS})}$ : RMS value of forward diode current

$\mathrm{V}_{\mathrm{r}} \quad$ : reverse voltage

$\mathrm{V}_{\mathrm{r}_{-} \text {ref }}$ : reverse voltage from datasheet

$I_{d \_r e f}:$ forward current from datasheet

$i_{d} \quad$ : diode current

$\mathrm{f}_{\mathrm{sw}} \quad$ : switching frequency

Power loss $\mathrm{P}_{\mathrm{L}_{\text {t total }}}$ is the sum of power losses of IGBTs and diodes.

SIMULATIONS OF THE PROPOSED CONTROL METHOD FOR LOW-COST SINGLE STAGE THREE-PHASE PV SYSTEM

Whole simulation model is built in Matlab/Simulink with SimPowerSystem Toolbox (Fig.8).

The simulation model includes:

PV system: $\mathrm{V}_{\mathrm{OC}}=800 \mathrm{~V}, \mathrm{I}_{\mathrm{SC}}=4 \mathrm{~A}, \mathrm{P}_{\max }=2380$ $\mathrm{W}$ (normal irradiation).

2-level inverter : Switch parameters: $\mathrm{R}_{\mathrm{CEO}}=0.05 \Omega, \mathrm{V}_{\mathrm{CEO}}=2.5 \mathrm{~V}, \mathrm{E}_{\text {on }}=0.005, \mathrm{E}_{\text {off }}=0.006$, $\mathrm{V}_{\mathrm{CE} \_\mathrm{bl}} /\left(\quad \mathrm{V}_{\mathrm{CE} \_ \text {ref. }} \quad \mathrm{I}_{\mathrm{C} \_ \text {ref }}\right)=0.0117 ; \quad \mathrm{R}_{\mathrm{D}}=0.01 \Omega$, $\mathrm{V}_{\mathrm{D}}=0.8 \mathrm{~V}, \mathrm{E}_{\mathrm{rr}}=0.006, \mathrm{~V}_{\mathrm{r}} /\left(\mathrm{V}_{\mathrm{r} \_ \text {ref. }} \mathrm{I}_{\mathrm{d} \_ \text {ref }}\right)=0.0117$.

Filter: $\mathrm{L}=50 \mathrm{mH}$.

Grid phase voltage: $\mathrm{V}_{\mathrm{g}}=220 \mathrm{Vrms}, \mathrm{f}=50 \mathrm{~Hz}$ 
Irradiation : $0 \leq \mathrm{t} \leq 0.5 \mathrm{~s}, \mathrm{G}=1 ; 0.5 \leq \mathrm{t} \leq 1 \mathrm{~s}, \mathrm{G}$ $=0.7$.

The simulation results for the irradiation change case are shown in Fig.9.

The input power is measured to demonstrate the operation points of PV system easily. In addition, the estimated power can be used to plot and test without measuring input power. The estimation is based on expression (2), where $\mathrm{V}_{\mathrm{gd}}$ is grid phase voltage (rms) and $I_{d}$ is in rms (Fig.10a).

The grid current phase is identical to the grid voltage phase. When the irradiation changes, the magnitude of grid current is decreased (Fig.10b).

The efficiency of VSI is evaluated by using the estimation block (Fig.8c), which is based on expressions (6)-(9). The high efficiency of PV inverter is obtained as shown in Fig.10c, while the irradiation changes from 1 to 0.7 at $0.5 \mathrm{~s}$.

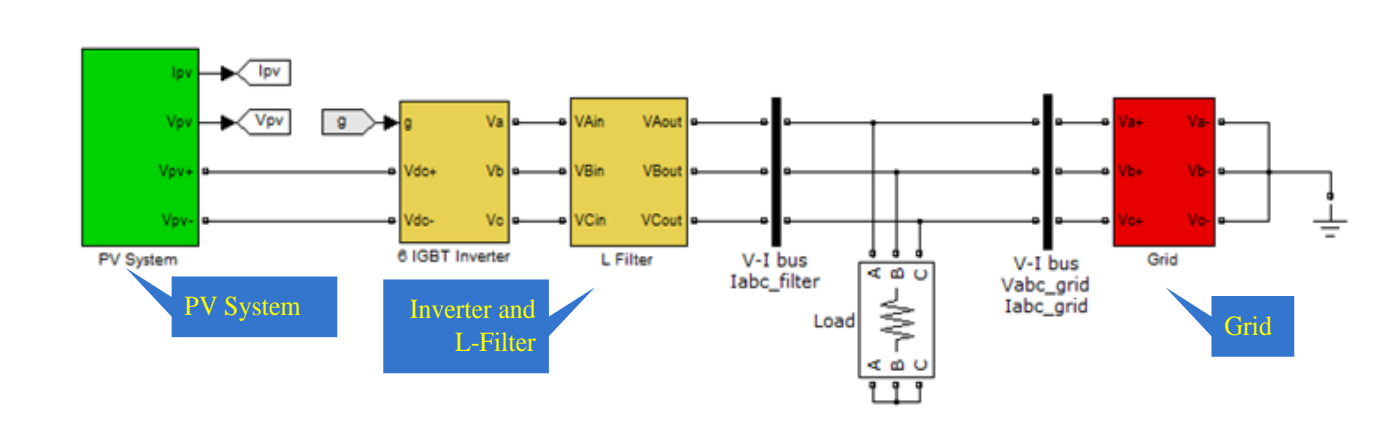

a) The low-cost single-stage three-phase grid connected PV system

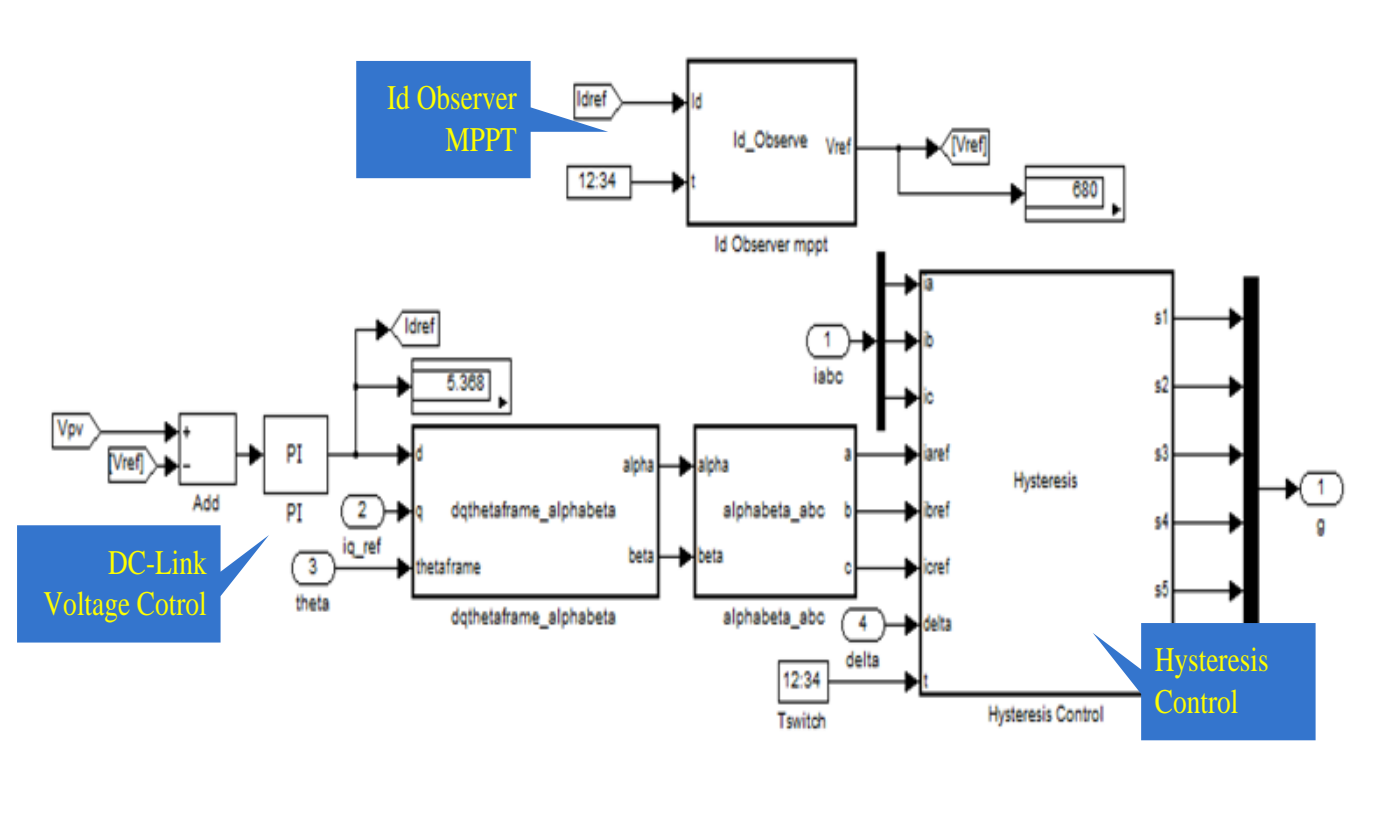

b) Control Block 


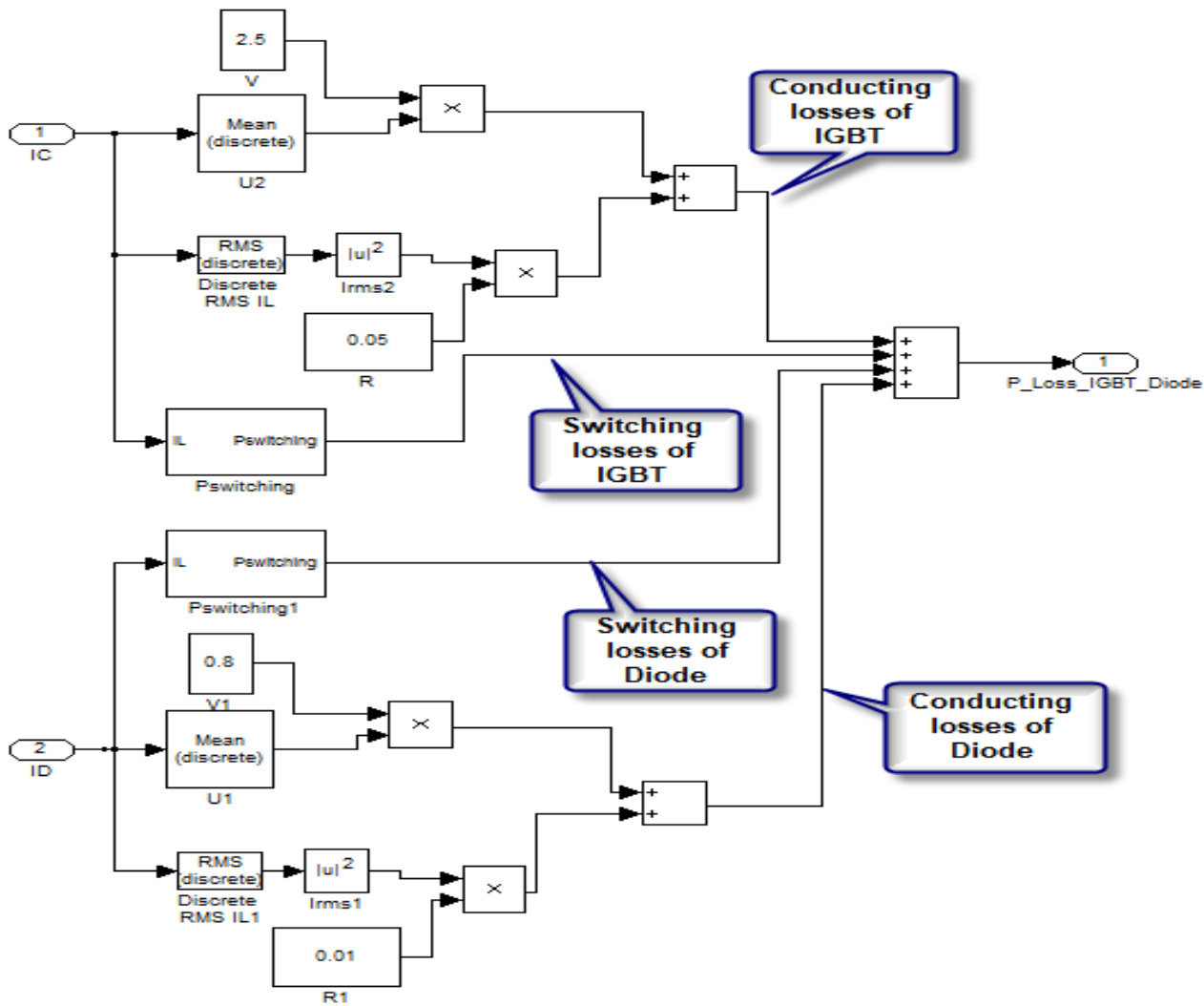

c) Efficiency estimation block for one pair of IGBT-Diode

Figure 8. The simulation model of proposed control algorithm

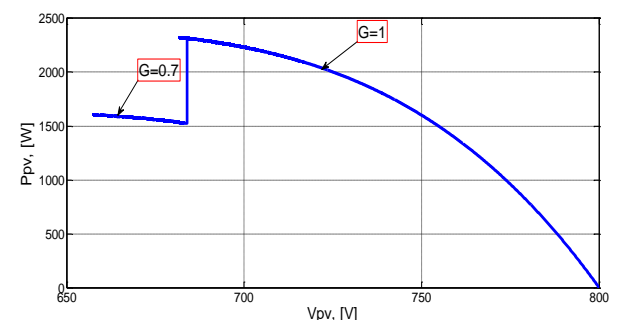

a) $\mathrm{P}-\mathrm{V}$ curve in normal irradiation $(\mathrm{G}=1)$ to $\mathrm{G}=0.7$

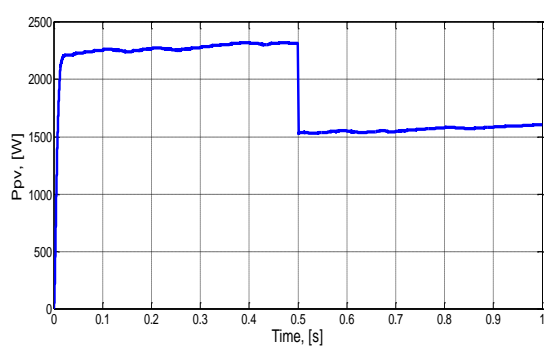

b) Input power characteristic

Figure 9. Simulation results of PV and input power characteristic 


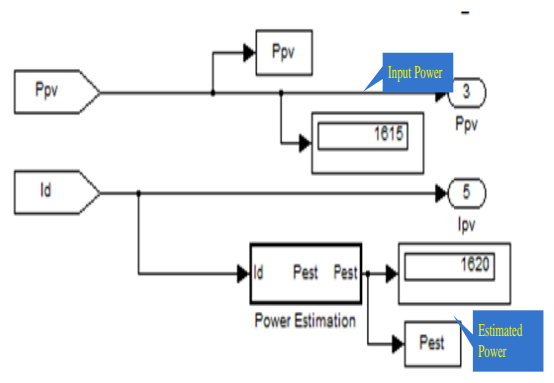

a) Input power and estimated power (Watt)

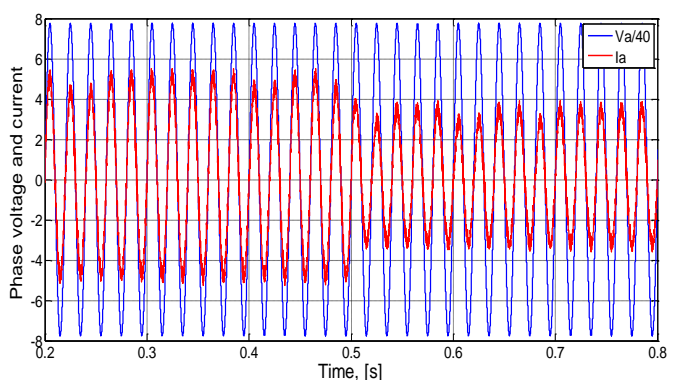

b) Grid phase current and voltage $(\mathrm{Va} / 40)$ waveform

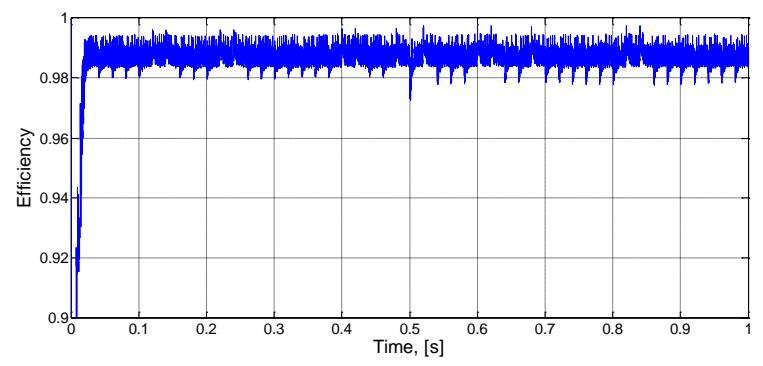

c) The efficiency characteristic of PV inverter

Figure 10. Simulation results of estimated power, grid current and voltage, efficiency

\section{EXPERIMENTAL RESULTS}

A prototype is used to verify the proposed algorithm. In the experiments, a PV system current sensor is additionally used to measure input power. Similar to simulation, an estimated power is calculated for plotting and checking based on the relationship expression between output power and $I_{d}$ value.

The experimental model (Fig. 11) includes:

PV system: 15 panels, Kyocera KC50T, installed in series

$\left\{V_{O C}=21.7 V, I_{S C}=3.31 A, P_{\max }=50 \mathrm{~W}:\right.$ everypanel

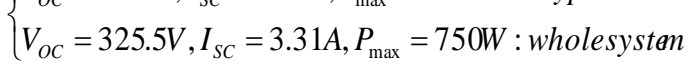

DC-link Capacitor: $1800 \mu \mathrm{F}, 400 \mathrm{~V}$ maximum

Controller: dSPACE 1103

2-level inverter : 6 IGBTs Fairchild G60N100

Driver : opto HCPL A3120

Voltage and current sensors: LEM LV-25P, LEM HX-20P

L-Filter: $\mathrm{L}=20 \mathrm{mH}$
Isolated Transformer: 370/75 V, line voltage

The Power Analyzer Fluke 43B is utilized to show the power factor, grid current harmonics...

The proposed control method is programmed by dSPACE 1103. The user interface (Fig.12), for controlling and plotting, is built in ControlDesk.

As shown in the Fig.12, the measuring value and the reference value is relatively equivalent, such as $V_{P v}$ and $I_{d}$. The estimated power is very close to the input power which determined by sensors. However, the estimated one is not completely steady. It slightly changes around the measured power. The secondary currents mean the current in the inverter side, not in the grid side because of step-up transformer.

The true $\mathrm{P}-\mathrm{V}$ curve, not estimated, is easier to observe the maximum power point (Fig.13a).

The algorithm control the secondary current phase to be the same as the grid voltage phase for unity power factor (Fig.13b). Because the grid 
voltage and the secondary votage have the same phase, the power which measured in the secondary side has the maximum power factor (Fig.14a).
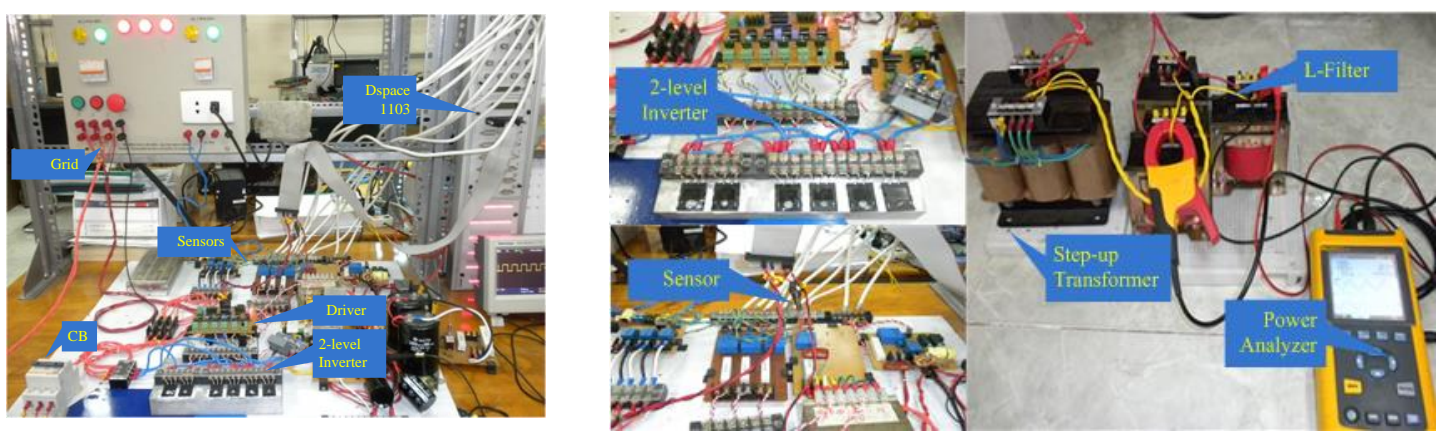

Figure 11. Experimental Model

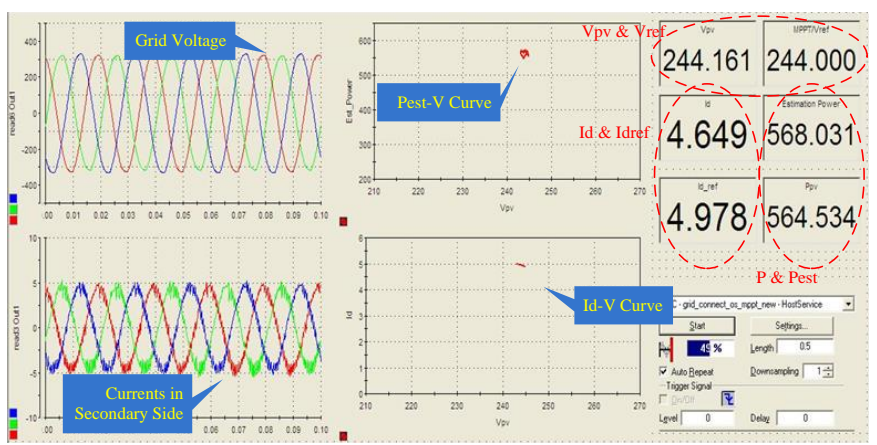

Figure 12. User Interface for monitoring, measuring voltage (V), current (A) and power (W)

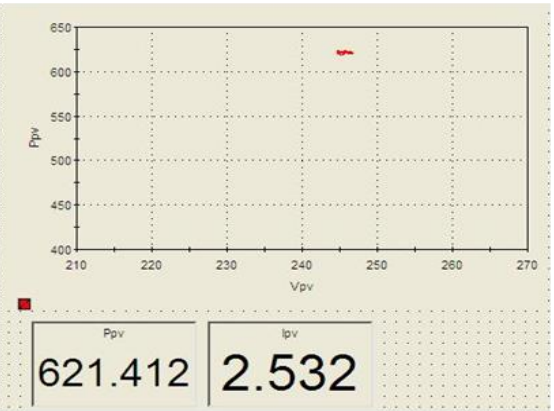

a) Power (w), current (A) and voltage(V) of PV, measured by sensors

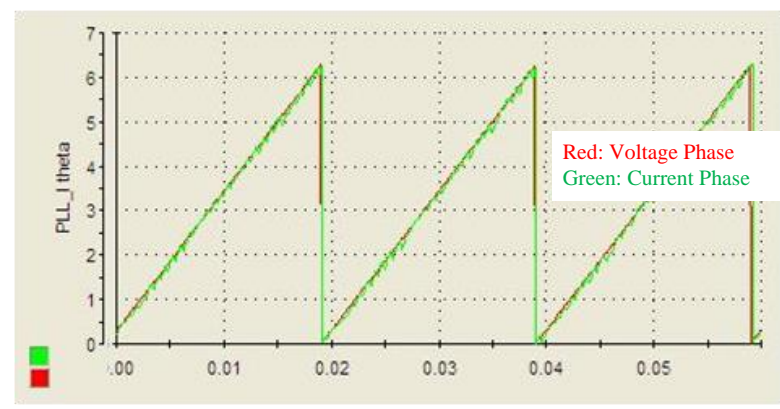

a) Grid voltage and current phase

Figure 13. Experimental results 


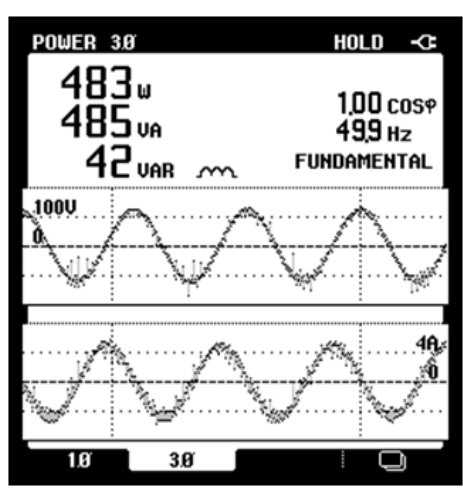

a) Power analysis in the secondary side

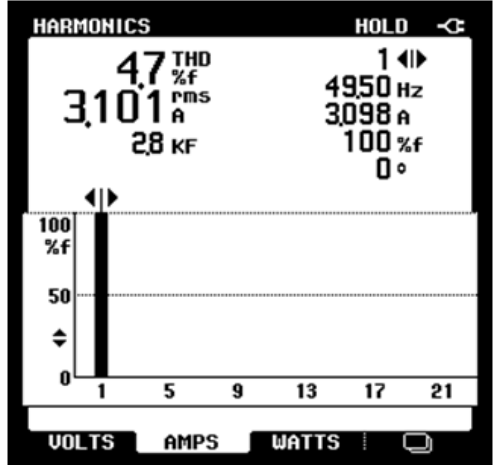

b) Inverter current analysis

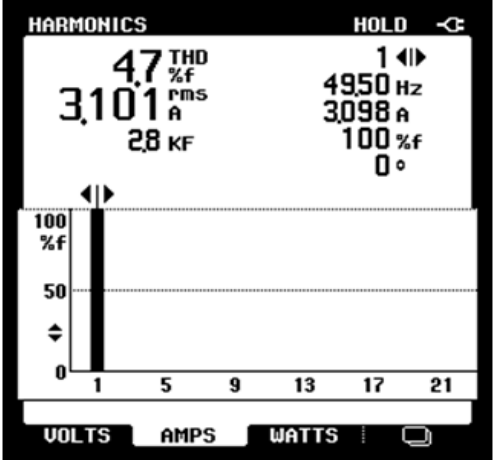

c) High order harmonics

Figure 14. Power quality analysis

The quality of output currents is shown in Fig.14b. The THD is smaller than 5\% and can be reduced when the PV system power increases. The magnitude of high order harmonics is much smaller than the basic harmonic (Fig14c).

The experimental results demonstrate good responses as shown in above figures. The responses of electrical quantities in low-cost single-stage three-phase PV system are obtained quickly and precisely.

\section{CONCLUSION}

This paper presented a modified control method for single-stage three-phase gridconnected PV system, which has the advantages of the high efficiency, cost-effectiveness and simplicity. Unlike other MPPT methods, the input power is substituted by $I_{d}$ value which is easy to calculate. Moreover, the output power, actually $I_{d}$, is observed to replace the input power. Hence, the PV array output current sensor can be removed. Beside that, the proposed MPPT algorithm is based on the method with variable step change of $V_{\text {ref }}$ in order to accelerate the MPPT response.

In this work, the hysteresis current control and L-filter are implemented. Advanced methods of current control, such as PI, deadbeat, and LCLfilter could be considered to improve the quality of grid currents. The DC-link voltage balancing principle has been used. However, other configurations are being researching to apply this new MPPT idea possibly.

The simulation results validate the performance of the proposed schema. Experiments performed with a laboratory prototype have shown encouraging results.

Acknowledgment: This research is funded by Vietnam National University - HCM City, Vietnam under grant number B2012-20-04TĐ. 


\section{Phương pháp điều khiển cải tiến cho hệ thống điện mặt trời kết lưới ba pha cấu trúc một tầng}

- Phan Quốc Dũng

- Nguyễn Trường Đan Vũ

- Lê Đình Khoa

- Nguyễn Bảo Anh

- Lê Chí Hiệp

Trường Đại học Bách khoa, ĐHQG-HCM

\section{TÓM TÁT:}

Cấu hình một tầng và thuật toán dò tìm điểm công suất cực đại (MPPT) có ưu điểm vì đơn giản và hiệu suất cao khi kết lưới nguồn pin mặt trời $(P V)$. Trong các hệ truyền thống, cảm biến dòng và áp của hệ thống $P V$ được sử dụng để thực hiện MPPT. Bài báo này trình bày một thuật toán cải tiến cho hệ thống PV kết lưới ba pha, cấu trúc một tầng, không sử dụng cảm biến dòng với bước dò tìm MPP tự động thay đổi nhằm rút ngắn thời gian thực thi. Thuật toán này

không cần giải tích từ các công thức tính toán phức tạp và không phụ thuộc vào bất cứ thông số mạch nào. Thuật toán cho phép tính toán công suất ngõ ra của bộ nghịch lưu thay vì công suất ngõ vào của $P V$ khi thực hiện MPPT. Thuật toán cải tiến được mô phỏng bằng Matlab/Simulink và được kiểm chứng bằng thực nghiệm. Cấu hình một tầng và không dùng cảm biến dòng thích hợp cho các ứng dụng giá thành thấp và hiệu suất cao.

Từ khóa: cấu hình một tầng, điểm năng suất cực đại, hệ thống PV.

\section{REFERENCES}

[1]. Trishan Esram, Patrick L. Chapman, Comparison of Photovoltaic Array Maximum Power Point Tracking Techniques, IEEE Trans. Energy Conversion, vol 22, No.2 June 2007.

[2]. K. H. Hussein and I. Mota, Maximum photovoltaic power tracking: An algorithm for rapidly changing atmospheric conditions, in IEE Proc.Generation Transmission Distribution, 59-64 (1995).
[3]. S. Jain and V.Agarwal, A new algorithm for rapid tracking of approximate maximum power point in photovoltaic systems, IEEE Power Electronics Letters, vol. 2, no. 1, 1619, March 2004.

[4]. A. Brambilla, M. Gambarara, A. Garutti, and F. Ronchi, New approach to photovoltaic arrays maximum power point tracking, in Proc. 30th Annual IEEE Power Electronics Specialist Conference, 632-637 (1999). 
[5]. J. J. Schoeman and J. D. van Wyk, A simplified maximal power controller for terrestrial photovoltaic panel arrays, in Proc. 13th Annual IEEE Power Electronics Specialist Conference, 361-367 (1982).

[6]. C. Y. Won, D. H. Kim, S. C. Kim, W. S. Kim and H. S. Kim, A new maximum power point tracker of photovoltaic arrays using fuzzy controller, in Proc. 25th Annual IEEE Power Electronics Specialist Conference, 396-403 (1994).

[7]. T. Hiyama, S. Kouzuma and T. Imakubo, Identification of optimal operating point of $P V$ modules using neural network for real time maximum power tracking control, IEEE Trans. Energy Conversion, vol. 10, no. 2, 360-367, Jun (1955).

[8]. Il-Song Kim, Myung-Bok Kim and MyungJoong Youn, New Maximum Power Point Tracker Using Sliding-Mode Observer for Estimation of Solar Array Current in the Grid-Connected Photovoltaic System, IEEE Transactions on Industrial Electronics, vol. 53, no. 4, August 2006.

[9]. N. Kasa, T. Lida and H. Iwamoto, Maximum power point tracking with capacitor identifier for photovoltaic power system, Proc. Inst. Electr.Eng.-Electr. Power Appl., vol. 147, no. 6, 497-502, Nov. 2000.

[10]. T. J. Liang, Y. C. Kuo and J. F. Chen, Single-stage photovoltaic energy conversion system, Proc. Inst. Elect. Eng., vol. 148, no. 4, 339-344 (2001).

[11]. Y. Chen and K. M. Smedley, "A costeffective single-stage inverter with maximum power point tracking," IEEE Trans. Power Electron., vol. 5, no. 19, pp. 1289-1294, Sep. 2004.

[12]. Wu Libo, Zhao Zhengming and Liu Jianzheng, A Single-Stage Three- Phase
Grid-Connected Photovoltaic System With Modified MPPT Method and Reactive Power Compensation, IEEE Transactions on Energy Conversion, vol. 22, pages 881, December 2007.

[13]. Patel, H.; Agarwal, V.; , MPPT Scheme for a PV-Fed Single-Phase Single-Stage GridConnected Inverter Operating in CCM With Only One Current Sensor, Energy Conversion, IEEE Transactions on, vol.24, no.1, pp.256-263, March 2009.

[14]. Tsai-Fu Wu; Chih-Hao Chang; Li-Chiun Lin; Chia-Ling Kuo; Power Loss Comparison of Single- and Two-Stage Grid-Connected Photovoltaic Systems, Energy Conversion, IEEE Transactions on, vol.26, no.2, 707-715, June 2011.

[15]. Ghoddami, H.; Yazdani, A.; , A SingleStage Three-Phase Photovoltaic System With Enhanced Maximum Power Point Tracking Capability and Increased Power Rating, Power Delivery, IEEE Transactions on, vol.26, no.2, 1017-1029, April 2011.

[16]. F. Blaabjerg, R. Teodorescu, M. Liserre and A. Timbus, Overview of control and grid synchronization for distributed power generation systems, IEEE Transactions on Industrial Electronics, Vol. 53, No. 5, 13981409 (2006).

[17]. A. Timbus, M. Liserre, R. Teodorescu, P. Rodriguez and F. Blaabjerg, Linear and nonlinear control of distributed power generation systems, Proceedings of IAS'06, pages 1015-1023, (2006).

[18]. E. Twining and D. G. Holmes, Grid current regulation of a three-phase voltage source inverter with an LCL input filter, IEEE Trans. Power Electronics, vol. 18, no. 3, 888-895, May 2003.

[19]. L. A. Serpa, S. Ponnaluri, P. M. Barbosa and J. W. Kolar, A Modified Direct Power 
Control Strategy Allowing the Connection of Three-Phase Inverters to the Grid Through LCL Filters, IEEE Trans. on Industry Applications, vol. 43, 1388-1400, September 2007.

[20]. Dusan Graovac, IGBT power losses calculation using the datasheet parameters, Application Note, V 1.1, January 2009.

[21]. Uwe Drofenik, Johann W.Kolar, A general scheme for calculation switching and conduction losses of power simmiconductor in power numerical circuit simulation of power electronic systems, IPEC 2005.

[22]. Weimin Wu; Xiaoli Wang; Pan Geng; Tianhao Tang, Efficiency analysis for three phase grid-tied $P V$ inverter, Industrial Technology, 2008. ICIT 2008. IEEE International Conference on, vol., no., 1,5, 21-24 April 2008.

[23]. M.H Bierhoff, F.W. Fuchs, Semiconductor losses in Voltage source and current source IGBT converter based on analytical derivation, PESC 2004. 